\title{
Penyusunan Bahan Ajar Pengembangan Kognitif Melalui Pendekatan Iceberg Pada Anak Kelompok TK B
}

\author{
Aprilia Dwi Handayani' 1 , Dema Yulianto², Samijo 3 , Dian Devita Yohanie ${ }^{4}$, Darsono ${ }^{5}$ \\ apriliadwi@unpkediri.ac.id'; yulianto.dema@gmail.com²; sammatunp@gmail.com³, \\ diandevita@unpkediri.ac.id ${ }^{4} ;$ darsono@unpkediri.ac.id ${ }^{5}$ \\ Program Studi Pendidikan Matematika 1,3,4,5, Program Studi PG PAUD2 \\ Universitas Nusantara PGRI Kediri 1,2,3,4,5
}

\begin{abstract}
One of the cognitive developments that must be considered at kindergarten age is the ability to count, which includes the concept of addition and subtraction. In fact, not all kindergarten age children can understand well the mathematical concepts presented in mathematical symbols. In addition, some kindergarten-age children still have difficulty adding numbers abstractly. There are also students who are less able to write down the number of objects in numeric symbols. Therefore, to optimally support the cognitive development of Kindergarten Group $\mathrm{B}$, the right stimulants are needed in the learning process. So that teaching material is compiled based on Iceberg's theory to develop children's cognitive abilities in the concept of counting. This study aims to develop teaching materials to introduce the concept of addition and subtraction for Kindergarten group $B$ using the Iceberg approach. This research is development research carried out in 4D stages, namely, define, design, develop and disseminate. The results of this study indicate that the teaching materials arranged are included in the feasible category and can be used to support teaching materials for numeracy in kindergarten age children.
\end{abstract}

Keywords: iceberg approach, cognitive development, kindergarten, teaching material

\begin{abstract}
Abstrak
Salah satu perkembangan kognitif yang harus diperhatikan usia TK adalah kemampuan berhitung yang mencakup konsep penjumlahan dan pengurangan. Faktanya, tidak semua anak usia TK dapat memahami dengan baik konsep matematika yang disajikan dalam simbol matematika. Selain itu, sebagian anak usia TK masih mengalami kesulitan dalam menjumlahkan angka-angka secara abstrak. ada pula siswa yang kurang mampu menuliskan banyaknya benda dalam simbol angka. Oleh karena itu, untuk mendukung perkembangan kognitif anak kelompok TK B secara optimal diperlukan stimulan yang tepat dalam proses pembelajaran. Sehingga disusun sebuah bahan ajar yang berdasarkan pada teori lceberg untuk mengembangkan kemampuan koginitif anak dalam konsep berhitung. Penelitian ini bertujuan untuk mengembangkan bahan ajar untuk memperkenalkan konsep penjumlahan dan pengurangan bagi TK kelompok $B$ dengan menggunakan pendekatan Iceberg. Penelitian ini merupakan penelitian pengembangan yang dilaksanakan dalam tahapan 4D yaitu, define, design, develop dan disseminate. Hasil dari penelitian ini menunjukkan bahan ajar yang disusun termasuk dalam kategori layak dan dapat digunakan untuk menjadi bahan ajar penunjang pembelajaran berhitung pada anak usia TK.
\end{abstract}

Kata Kunci: pendekatan iceberg, perkembangan kognitif, siswa TK, bahan ajar 


\section{PENDAHULUAN}

Perkembangan kognitif pada anak usia TK masih berada pada tahap pra operasional. Salah satu kemampuan kognitif yang harus diperhatikan pada anak usia TK diantaranya adalah kemampuan berhitung yang mencakup konsep penjumlahan dan pengurangan. Konsep matematika yang abstrak tidak selalu dapat diterima dengan baik oleh siswa usia TK. Oleh karena itu, pemberian stimulan yang tepat sangat diperlukan untuk mendukung perkembangan anak secara optimal. Sebagian siswa TK masih mengalami kesulitan dalam menjumlahkan angka-angka secara abstrak. Ada pula yang kesulitan dalam proses berhitung, baik menguarngi amupun menjulahkan. Selain itu, ada pula siswa yang kurang mampu menuliskan banyaknya jumlah benda ke dalam simbol angka.

Perkembangan kognitif usia 3 sampai 6 tahun berada pada tahap praoperasional yaitu (1) Menggunakan simbol, dimana anak tidak harus kontak sensorimotor dengan objek. Anak dapat membayangkan objek atau orang tersebut memiliki sifat yang berbeda dengan yang sebenarnya; (2) Mema-hami identitas, dimana anak memahami bahwa perubahan yang terjadi tidak meru-bah karakter ilmiah; (3) Memahami sebab akibat, dimana anak memahami bahwa suatu peristiwa ada sebabnya, (4) Mampu mengklasifikasi, anak mengelompokkan ob-jek, orang, suatu peristiwa ke dalam kategori yang bermakna, (5) Memahami angka, dima-na anak dapat menghitung dan memahami angka Karakteristik perkembangan kognitif tahap praoperasional antara lain: menge-lompokkan benda yang memiliki persamaan, menghitung 120, mengenal bentuk-bentuk sederhana, memahami konsep makna ber-lawanan, mampu membedakan bentuk ling-karan atau persegi dengan objek nyata atau gambar, memasangkan dan menyebutkan benda, mencocokkan bentuk-bentuk seder-hana, mengklasifikasikan angka, tulisan, buah dan sayur, mengenal huruf kecil dan besar, mengenal warna-warna. (Sujiono, 2014, p.2.16).

Perkembangan kognitif anak kelompok B1 di sebuah TK menurut Retnaningrum (2016) pada umumnya belum berkembang secara optimal. Data penelitian tersebut menunjukkan perkembangan kognitif anak masih dalam kategori mulai berkembang, anak baru mampu melakukan beberapa kegiatan pembelajaran yang mengembangkan aspek kognitif dan masih memerlukan stimulasi untuk mengembangkan aspek kognitif lebih lanjut. Perlu adanya perbaikan untuk meningkatkan perkembangan kognitif anak dalam proses pembelajaran yang lebih menarik, kreatif dan inovatif.

Penelitian terdahulu yang dilakukan oleh Novitasari (2016) menunjukkan bahwa sebagian siswa TK masih mengalami kesulitan dalam menjumlahkan angka-angka secara abstrak. Hal ini senada dengan hasil observasi awal dan wawancara yang yang dilakukan di sebuah sekolah TK. Tidak semua anak usia dini mempunyai kemampuan yang baik dalam berhitung. Ada yang siswa yang lama dalam berhitung dan sulit menghitung jumlah benda. Kesulitan lain yaitu menghubungkan jumlah benda dengan simbol atau menuliskan jumlah benda dalam bentuk angka. Pada tingkatan lanjut, siswa memiliki kesulitan dalam aritmatika sederhana yaitu penjumlahan dan pengurangan. Hasil yang serupa diperoleh dari 
penelitian Anwar (2011) yang menyebutkan bahwa subyek penelitian Anwar mengalami kesulitan dalam menyelesaikan soal pengurangan.

Mengingat berbagai kesulitan yang dapat dialami oleh siswa TK dalam mempelajari konsep penjumlahan dan pengurangan maka salah satu cara yang dapat digunakan untuk mengenalkan konsep penjumlahan dan pengurangan pada siswa TK yaitu dengan menggunakan pendekatan Iceberg. Iceberg dikenal sebagai fenomena gunung es. Sebagaimana diketahui bahwa proses pembentukan gunung es di laut pertama dimulai dari di bawah permukaan laut sebagai bagian dasar gunung es, selanjutnya terbentuk bagian yang lebih atas dan terbentuk puncak gunung es yang tampak di atas permukaan laut. Bagian dasar gunung es yang berada di dasar laut lebih luas dari pada bagian puncak gunung es yang nampak di atas permukaan laut. Oleh karena itu, konstruksi gunung es tersebut menjadi kokoh dan stabil. Seperti halnya fenomena gunung es, proses pengenalan konsep matematika dengan menggunakan pendekatan Iceberg berarti dalam model gunung es terdapat empat tingkatan aktivitas, yakni : 1) Orientasi lingkungan secara matematis, 2) Model Alat Peraga, 3) pembuatan pondasi (Building stone), dan 4) Matematika formal. Dengan langkah tersebut diharapkan siswa TK yang masih berada pada tahap pre operasional dapat lebih mudah memahami konsep matematika yang abstrak karena konsep tersebut diawalai dengan pengenalan dari benda-benda konkret di sekitar siswa.

Secara garis besar, Piaget (dalam Septiana, 2017), mengelompokkan tahapan perkembangan menjadi empat tahap kematangan kognitif pada anak, yang berurutan dan saling berkaitan. Pada usia TK, kemampuan koginitif siswa berada pada tahap praoperasi, anak- anak mulai menggunakan simbol untuk menunjukkan suatu benda dan mengungkapkan pemikirannya dengan menggunakan bahasa. Perkembangan kognitif yang harus diperhatikan pada anak usia TK diantaranya adalah kemampuan berhitung yang mencakup konsep penjumlahan dan pengurangan. Konsep matematika yang abstrak tidak selalu dapat diterima dengan baik oleh siswa usia TK. Untuk dapat mengenalkan operasi dasar matematika pada anak usia dini ternyata tidak mudah. Beberapa cara diantaranya adalah dengan melakukan operasi penjumlahan dan pengurangan dengan menggunakan benda-benda yang ada disekitar, misalnya dengan memakai lima pensil yang dapat digenggam. Untuk pengurangan, pensil tersebut dilepaskan atau diletakkan dan untuk penjumlahan, anak-anak dapat diminta mengambil lagi pensil sebanyak yang ditentukan. Cara tersebut merupakan salah satu contoh upaya untuk mengenalkan hakikat "bertambah" dan "berkurang".

Pendekatan Iceberg yang dilakukan untuk mengenalkan konsep penjumlahan dan pengurangan pada siswa TK diwujudkan dalam bentuk bahan ajar yang berupa buku aktivitas siswa. Dalam tahapan pertama Iceberg, pengenalan konsep penjumlahan dan pengurangan pada siswa diawali dengan menyajikan benda konkret pada siswa dan cerita tentang penjumlahan. Kedua, siswa diminta untuk menggambar benda yang telah disebutkan dalam tahap sebelumnya. Ketiga, siswa dikenalkan dengan konsep penjumlahan dan pengurangan dalam matematika. Pada tahap puncak Iceberg, siswa dikenalkan pada konsep formal tentang penjulahan dan pengurangan, termasuk mengenal tanda "plus" dan "minus". 
Hasil penelitian Retta (2016) menunjukkan bahwa siswa dapat memahami konsep perkalian dengan baik melalui makanan khas Palembang sebagai titik awal pembelajaran Iceberg. Oleh karena itu, dalam penelitian ini akan dikembangkan bahan ajar dengan pendekatan Iceberg untuk mengenalkan konsep penjumlahan dan pengurangan pada siswa TK dengan titik awal berupa benda konkret di sekitar lingkungan belajar

\section{METODE PENELITIAN Model Pengembangan}

Thiagarajan et al (1974) menyebutkan empat tahapan pengembangan model yaitu 4D yang meliputi 4 tahap yang disajikan dalam Gambar 1 berikut:

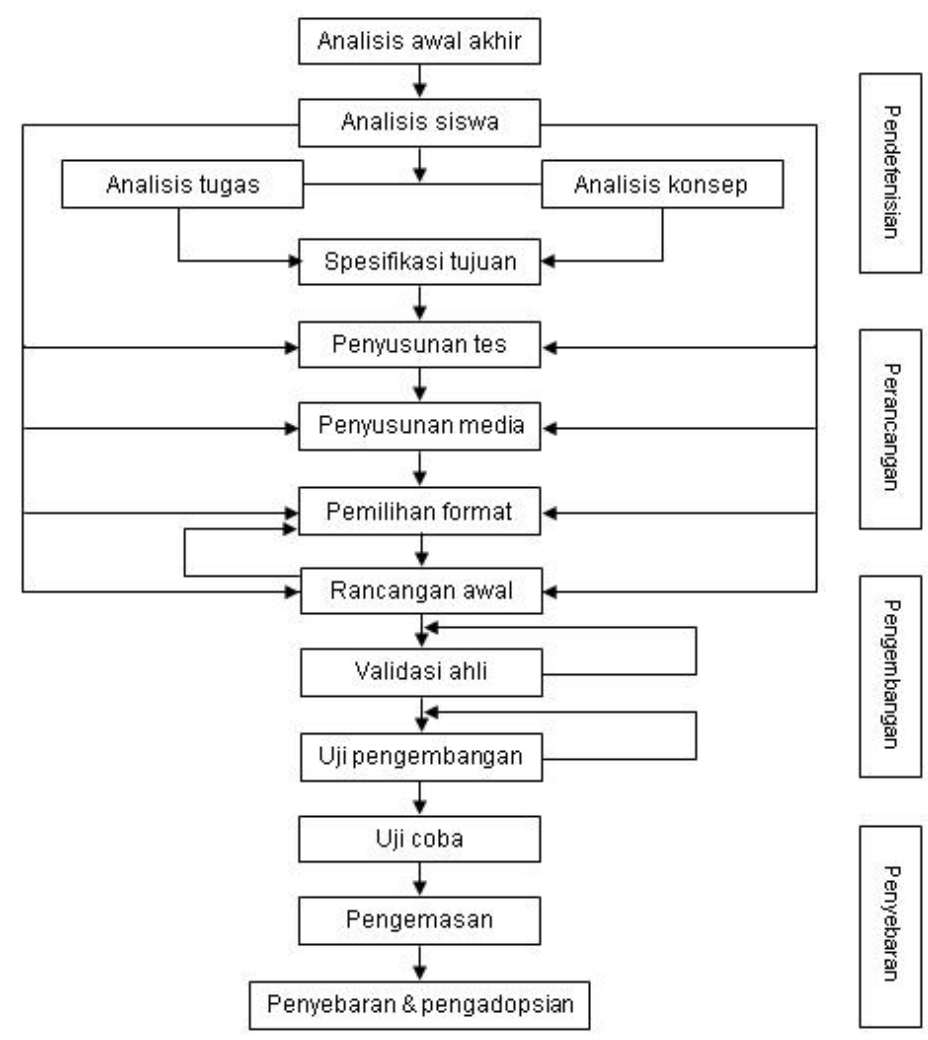

Gambar 1. Alur Penelitian melalui tahapan 4D

Dari Gambar 1 dapat diketahui ada empat tahapan penelitian pengembangan dengan tahapan 4D, yaitu tahap pertama, define (pendefinisian), tahap kedua adalah design (perancangan), tahap ketiga adalah develop (pengembangan) dan tahap ke empat adalah disseminate (penyebaran). Pemilihan model ini karena langkah-langkah kegiatan yang digunakan dalam model ini tersusun sistematis dan runtut sehingga dapat digunakan untuk pengembangan bahan ajar yang sesuai dengan tahapan pelaksanaan penelitian.

\section{Prosedur Pengembangan}

Tahap define (pendefinisian). Pada tahap ini, peneliti menetapkan serta mendefinisikan kebutuhan pembelajaran. Adapun langkah-langkah yang dilakukan pada tahap ini adalah menggali informasi berkaitan dengan rencana penyusunan bahan ajar penjumlahan dan pengurangan sesuai dengan pendekatan Iceberg. 
Tahap design (perancangan). Tujuan tahapan ini adalah untuk merancang bahan ajar untuk mengenalkan konsep penjumlahan dan pengurangan. Langkah-langkah pada tahap ini diawali dengan memilih media yang sesuai dengan tujuan pembelajaran, kemudian memilih format yaitu dengan mempelajari dan mengkaji format-format buku teks pelengkap yang ada dan menetapkan format yang sesuai untuk bahan ajar yang akan dikembangkan. Hasil dari tahapan ini adalah tersusunnya rancangan awal bahan ajar yang sesuai format dan materi yang akan diajarkan. Pada tahapan ini disusun bahan ajar tentang penjumlahan dan pengurangan yang sesuai dengan pendekatan Iceberg.

Tahap develop (pengembangan). Kegiatan yang dilakukan pada tahap ini adalah dengan merevisi dan memodifikasi prototype melalui kegiatan uji coba. Tahap pengembangan bertujuan untuk menghasilkan produk pengembangan yang dilakukan melalui dua langkah, yakni (1) validasi ahli dan dilanjutkan dengan revisi, (2) uji coba pengembangan. Uji coba in bertujuan untuk melengkapi dan menyempurnakan bahan ajar tentang penjumlahan dan pengurangan.

Tahap disseminate (penyebaran). Tahapan ini adalah tahap paling akhir dari sebuah pengembangan. Kegiatan yang dilakukan pada tahap ini adalah untuk mempromosikan produk pengembangan agar dapat diterima oleh sasaran pengguna, baik sebagai individu, kelompok, maupun dalam suatu sistem. Pada penelitian ini, tahap diseminasi dilakukan dalam tingkat terbatas, yakni hanya dalam lingkup TK yang digunakan sebagai tempat penelitian. Penyebarluasan bahan ajar dilakukan dengan mempromosikan bahan ajar penjulahan dan pengurangan untuk siswa TK secara umum

\section{HASIL DAN PEMBAHASAN Pendekatan Iceberg}

Gravemeijer (dalam Bito, 2014) menyebutkan, pada awalnya cara atau model yang digunakan siswa sesuai dengan apa yang dipahami siswa tersebut. Model yang dikembangkan pada tahap awal masih bersifat kontekstual dan khusus dari (model of) situasi masalah yang disajikan. Model tersebut kemudian menjadi dasar untuk mengembangkan pengetahuan tentang matematika dalam bentuk formal. Kemudian, secara bertahap, setelah melalui proses generalisasi dan formalisasi model tersebut diarahkan untuk menuju pada model untuk (model for) pemikiran matematika sesuai pada tingkat formal, baik berupa simbol maupun rumus.

Akan tetapi, ketika siswa belajar dengan menggunakan konteks nyata yang ada disekitarnya melalui bermain maupun mengamati fenomena di sekelilingnya, mereka seringkali tidak sadar bahwa sebenarnya mereka sedang belajar. Siswa tidak memahami bahwa apa yang sedang mereka mainkan, ada konsep matematika penting yang akan mereka dapatkan. Sehingga disinilah peran guru sebagai fasilitator untuk memfasilitasi siswa agar dapat menghubungkan pengalaman yang dialami siswa selama bermain dengan konsep matematika yang ingin dikenalkan pada siswa. Frans Morerlands menamakan ini sebagai tahap orientasi lingkungan secara matematis yaitu ketika guru menghubungkan pengalaman siswa secara matematis di kelas. Frans Moerlands (dalam Sugiman, 2011: 8) mendeskripsikan tipe pendekatan realistik dalam teori gunung es (iceberg) yang mengapung di tengah laut. Gunung es yang muncul dan tampak dipermukaan laut tersebut adalah bagian puncak gunnung es yang merupakan representasi dari konsep matematika formal dari materi 
yang dipelajari. Sedangkan pembentukan gunung es diawali dari bagian dasar gunung es yang berada di bawah permukaan laut sebagai representasi dari konteks nyata tentang suatu konsep matematika.

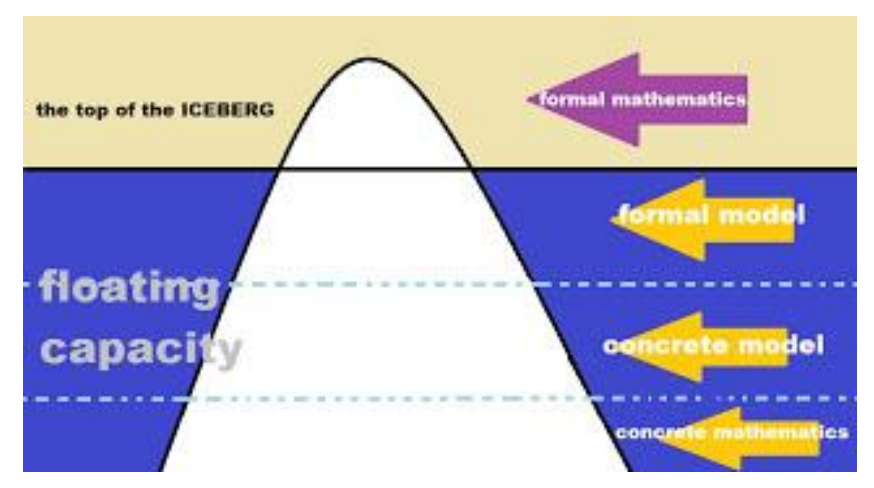

Gambar 2. llustrasi Iceberg pada pengenalan konsep matematika

Beberapa hal yang dapat dicermati dari Gambar 2 tentang ilustrasi gunung es adalah bahwa bagian dasar gunung es lebih luas dari pada puncaknya, dapat diartikan bahwa konstruksi gunung es tersebut pasti kokoh dan stabil. Oleh karena itu, terkait dengan pembentukan konsep matematika, matematika formal yang dillustrasikan sebagai puncak gunung es merupakan tujuan akhir dari pembelajaran tersebut. Sedangkan agar dapat mencapai tujuan, dibutuhkan upaya guru untuk mengenalkan konsep matematika secara sederhana berawal dari konteks nyata yang mudah dipahami oleh siswa sehingga konsep matematika siswa akan menjadi kuat dan kokoh. Moerlands menyebutkan empat tingkatan aktivitas dalam pendekatan iceberg, yaitu: (1) orientasi lingkungan secara matematis, (2) model alat peraga, (3) pembuatan pondasi (building stone), dan (4) matematika formal. Untuk menghubungkan kegiatan bermain dengan konsep yang akan dipelajari, orientasi kegiatan bermain secara matematis sangat penting. Pada tahap orientasi lingkungan secara matematis, siswa mempelajari matematika melalui konsep nyata yang ada di lingkungan sekitarnya. Pada tahapan ini anak belum ditunutut untuk mengenal matematika secara formal. Selanjutnya, anak mencoba memodelkan situasi nyata yang telah diberikan sebelumnya untuk selanjutnya pada tahap anak akan mengenal konsep matematika secara formal termasuk mengenal simbol dan angka serta tanda plus dan minus pada konsep penjumlahan dan pengurangan. Kegiatan matematis yang berkaitan dengan konteks real sehingga menuju pada suatu konsep matematika formal akan menjadi landasan yang kokok bagi anak untuk mempelajari matematika pada tingkat selanjutnya.

\section{Konsep Matematika dalam Perkembangan Kognitif Siswa TK}

Bagi anak yang sedang berada pada masa kanak-kanak awal atau masa pra sekolah, matematika sangat penting untuk mengembangkan kemampuan kognitif anaka, termasuk proses berpikir seorang anak. Pada tahap kognitif anak usia dini yang masih bersifat pra operasional, pembelajaran matematika yang diberikan baru bersifat pengenalan, belum kepada kepada konsep matematika yang sebenarnya. Pada pendidikan matematika dapat diberikan misalnya pada pengenalan penjumlahan dan pengurangan bilangan, terlebih dahulua anak dikenalkan dengan banyaknya benda yang merepresentasikan nilai suatu 
bilangan. Misalkan diwali dengan menghitung "dua pensil" dan menyebutkan banyaknya pensil sebanyak dua. Selanjutnya untuk mengenalkan konsep penjulahan, siswa diminta mengambil pensil dengan jumlah tertentu dan menghitung jumlahnya. Sedangkan untuk mengenalkan konsep pengurangan, siswa diminta untuk meletakkan beberapa pensil yang diegnggamnya kemudian menghitung jumlahnya setelah beberapa pensil diletakkan. Dengan berkembangnya kecerdasan dan usia, kemampuan kognitif anak pun akan berkembang. Sehingga pembelajaran dapat dilanjutkan ke tahap berikutnya.

Matematika merupakan ilmu pasti yang menjadi dasar bagi ilmu lain, sehingga matematika saling berkaitan erat dengan ilmu lain. Matematika dapat pula menjadi bahasa, sebab matematika merupakan bahasa simbol yang berlaku secara universal dan sarat makna serta pengertian. Sedangkan matematika sebagai seni dapat diartikan bahwa dalam matematika terlihat adanya keteraturan dan konsistensi. Matematika juga juga disebut sebagai ratunya imu pengetahuan, hal ini dapat dimaknai sebagai bahasa, ilmu dedukti, ilmu tentang keteraturan, ilmu tentang struktur yang terorganisasikan dengan baik dan ilmu yang menjadi pelayan bagi ilmu lainnya (Fitria, 2013). Standar Matematika untuk anak usia dini menurut NCTM (National Council of teachers of Mathematics )adalah sebagai berikut : 1. Angka dan pengoperasiannya. Yaitu salah satu kemampuan bermatematika yang digunakan anak dalam konsep bilangan atau pemahaman angka, yang membuat hubungan antara pengoperasiannya dan angkanya ditandai dengan penambahan dan pengurangan. 2. Aljabar, yaitu salah satu kemampuan bermatematika yang digunakan anak dalam sistematika angka yang memiliki pola secara natural dan terstruktur . 3. Geometri Anak mengenal bentuk-bentuk geometri 4. Pengukuran yaitu salah satu kemampuan bermatematika yang digunakan anak, melibatkan angka untuk mengetahui ukuran suatu benda jadi angka yang merupakan hasil dari pengukuran itu, dapat dibandingkan pada benda yang sejenis.

Tahapan Memperkenalkan Matematika pada Anak Usia Dini. Tiga tahapan penguasaan kemampuan berhitung : 1. Penguasaan Konsep. Penguasaan konsep merupakan tahap yang diawali dengan membentuk pemahaman atau pengertian tentang konsep matematika dengan menggunakan benda nyata, seperti pengenalan warna, bentuk, dan menghitung benda/bilangan. 2. Masa Transisi yaitu proses berpikir yang merupakan masa peralihan dari pemahaman konkrit menuju pengenalan lambang matematika yang abstrak, dimana benda nyata itu masih ada dan mulai dikenalkan bentuk lambangnya. 3 . Lambang, yaitu visualisasi dari berbagai konsep. Contonya lambang "7" untuk menggambarkan konsep bilangan tujuh, merah untuk melambangkan konsep warna merah (Pesona \& Vol, 2003).

Tujuan pembelajaran matematika sejak usia dini terbagi menjadu dua, yaitu tujuan umum dan tujuan khusus. Tujuan umum pembelajaran matematika yaitu supaya anak mengetahui dasar-dasar pembelajaran berhitung/ matematika. Harapannya pada saatnya nanti anak akan lebih siap mengikuti pembelajaran matematika dengan konteks yang lebih luas dan kompleks pada jenjang pendidikan yang lebih tinggi. Sedangkan tujuan khusus pembelajaran matematika yaitu agar siswa dapat berpikir logis dan sistematis sejak usia dini melalui pengamatan dan pengalaman yang dilakukan terhadap benda benda nyata, gambar- 
gambar atau angka-angka yang dijumpai di sekitar anak, serta anak dapat menyesuaikan dan melibatkan diri dalam kehidupan masyarakat yang dalam kesehariannya memerlukan keterampilan berhitung. Selain itu anak juga diharapakan memiliki ketelitian, konsentrasi, abstraksi dan daya apresiasi yang tinggi, memiliki kreativitas dan imajinasi dalam menciptakan sesuatu secara spontan.

\section{Hasil Tahapan Pengembangan Bahan Ajar}

Tahapan pengembangan bahan ajar berupa lembar aktivitas siswa tersebut dapat diuraikan sebagai berikut :

\section{Tahap Define (Pendefenisian)}

Kegiatan yang dilakukam peneliti pada tahap ini adalah mengidentifikasi dan menyusun secara sistematis materi-materi utama yang akan dipelajari peserta didik. Adapun materi yang akan disampaikan melalui bahan ajar ini agar anak dapat mengenal konsep penjumlahan dan pengurangan sebagai konsep dasar dalam operasi hitung.

\section{Tahap Design (Perancangan)}

Hasil analisis pada tahap design dijadikan sebagai dasar dalam pengembangan bahan ajar untuk anak usia dini kelompok B. Bahan ajar di desain untuk mengenalkan konsep penjumlahan dan pengurangan dengan menggunakan pendekaan Iceberg.

\section{Tahap Develop (Pengembangan)}

Tahap ini untuk menghasilkan bentuk akhir media pembelajaran setelah melalui revisi berdasarkan masukkan dari para ahli dan data hasil uji coba.

\section{Tahap Penyebaran (disseminate)}

Setelah dilakukan uji coba terbatas dan media telah direvisi/diperbaiki, maka tahap selanjutnya adalah tahap penyebarluasan. Tujuan dari tahap ini adalah menyebarluaskan bahan ajar dalam hal ini adalah lembar aktivitas siswa sebagai hasil dari proses pengembangan di tahap sebelumnya. Akan tetapi, dalam penelitian ini belum dapat dilakukan karena keterbatasan peneliti. Dengan demikian, penelitian pengembangan lembar aktivitas siswa menurut model 4-D sampai pada tahap pengembangan (develop) atau tahapan uji coba pengembangan. Sedangkan hasil validasi dari pengembangan bahan ajar berupa lembar aktivitas siswa tersebut dapat diuraikan sebagai berikut

\section{Data Hasil Ujicoba Ahli Media Terhadap Produk Lembar Aktivitas Siswa}

Ujicoba ahli media dilakukan untuk mendapatkan informasi yang akan digunakan untuk merevisi lembar aktivitas siswa yang dikembangkan. Hasil ujicoba diperoleh dengan cara penilaian melalui lembar kuisioner. Penilaian dilakukan setelah validator mengkaji lembar aktivitas siswa yang dikembangkan.Berdasarkan pada uji ahli media didapatkan bahwa kriteria lembar aktivitas siswa berada pada kriteria "sangat valid" dengan rata-rata skor yang diperoleh $92 \%$. 


\section{Kriteria Ahli Desain Pembelajaran Terhadap Produk Lembar Aktivitas Siswa}

Ujicoba ahli desain pembelajaran dilakukan untuk mendapatkan informasi yang akan digunakan untuk merevisi desain lembar aktivitas siswa yang dikembangkan. Hasil ujicoba diperoleh dengan cara penilaian melalui lembar kuisioner. Penilaian dilakukan setelah validator mengkaji lembar aktivitas siswa yang dikembangkan. Berdasarkan pada uji ahli desain pembelajaran didapatkan bahwa kriteria lembar aktivitas siswa berada pada kriteria "sangat valid" dengan rata-rata skor yang diperoleh $93 \%$.

\section{Kriteria Uji Ahli Materi Terhadap Produk Lembar Aktivitas Siswa}

Ujicoba ahli materi dilakukan untuk mendapatkan informasi yang akan digunakan untuk merevisi lembar aktivitas siswa yang dikembangkan. Hasil ujicoba diperoleh dengan cara penilaian melalui lembar kuisioner. Penilaian dilakukan setelah validator mengkaji bahan lembar aktivitas siswa yang dikembangkan. Berdasarkan pada uji ahli materi didapatkan bahwa kriteria lembar kerja anak berada pada kriteria "sangat valid" dengan rata-rata skor yang diperoleh $94 \%$.

\section{Data Hasil Ujicoba Perorangan Sebagai Pengguna Produk Lembar Aktivitas Siswa}

Ujicoba produk perorangan kepada dua anak usia TK kelompok B sebagai pengguna produk. Tahap ini dilakukan untuk mendapatkan informasi yang akan digunakan untuk merevisi kelayakan lembar aktivitas siswa yang dikembangkan. Berdasarkan hasil ujicoba perorangan dengan dua anak usis TK kelompok B bahwa lembar aktivitas siswa sudah jelas dan dapat digunakan untuk anak usia dini. Ujicoba ini bertujuan untuk mengetahui keterlakasanaan dan respon awal anak terhadap produk yang dikembangkan sehingga dapat diketahui dan diidentifikasi kesalahan yang nyata dalam produk tersebut. Berdasarkan kriteria kelayakan produk skor tersebut termasuk dalam kategori "sangat valid" sehingga lembar kerja anak layak digunakan.

\section{SIMPULAN}

Berdasarkan hasil penelitian dan pembahasan, maka dapat disimpulkan bahwa pengembangan lembar aktivitas siswa untuk mengenalkan konsep penjumlahan dan pengurangan bagi usia TK Kelompok B dengan menggunakan pendekatan Iceberg, setelah dilakukan ujicoba kepada ahli media, ahli desain pembelajaran dan ahli materi dan siswa sebagai pengguna produk menunjukkan hasil yang sangat valid. Dengan demikian, berdasarkan hasil ujicoba lembar aktivitas siswa tentang materi penjumlahan dan pengurangan dengan menggunakan pendekatan Iceberg layak untuk digunakan sebagai bahan untuk memperkenalkan operasi hitung dasar pada anak usia TK kelompok B.

\section{DAFTAR RUJUKAN}

Anwar, R,B. (2011) Analisis Kesulitan Belajar Matematika pada Anak Usia Dini (Tingkat Pra Sekolah/Tk) dan Alternatif Pemecahannya. Guidena Vol 1 No 1, September 2011.

Septiana, R; dkk. (2017). Mengenal Ukuran dengan Pendekatan PMRI pada Aspek Kognitif Pendidikan Anak Usia Dini. Volume 6 No 2 Desember 2017 hal 137-148. 
Mongkek, M.F, Ngura,E.T dan Rwewo, J.M. 2019. Pengembangan Lembar Kerja Anak Sebagai Bahan Ajar Untuk Perkembangan Aspek Moral Anak Usia 5-6 Tahun Di TKK Satap Rutosoro. PAUDIA Volume 8, No. 2, November 2019, pp. 88-94.

Novitasari, W. (2016) Analisis Kesulitan Belajar Matematika Anak Usia 5-6 Tahun. Jurnal Eksakta Vol 12016 hal 19-25.

Bito, G.S. (2014). Aktivitas Bermain sebagai Konteks dalam Belajar matematika di Sekolah Dasar. Jurnal pemikiran dan Pengembangan SD Jilid 1 no 4 hal 250-255.

Sugiman. (2011) Peningkatan pembelajaran Matematika Dengan menggunkaan pembeljaran matematika Realistik.

Fitria, A. (2013). Mengenalkan dan Membelajarkan Matematika Pada Anak Usia Dini. Jurnal Studi Gender Dan Anak, 1(2), 45-55.

Haji, Saleh. (2013). Pendekatan Iceberg dalam Pembelajaran Pembagian Pecahan di Sekolah Dasar. Infinty Jurnal IImiah Program Studi Pendidikan Matematika STKIP Siliwangi Bandung Vol 2 No 1 Februari 2013.

Pesona, J., \& Vol, P. (2003). Jurnal Pesona PAUD Vol. I No. 1, I(20).

Retnaningrum, W. 2016. Peningkatan Perkembangan Kognitif Anak Usia Dini Melalui Media Bermain Memancing. Jurnal Pendidikan dan Pemberdayaan Masyarakat Volume 3 - Nomor 2, November 2016, (207 - 218).

Sujiono, Y.N. (2014). Metode Pengembangan Kognitif. Tangerang Selatan: Universitas Terbuka. 